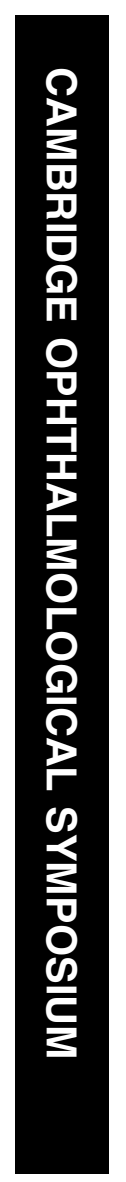

\title{
A history of the optic nerve and its diseases
}

\begin{abstract}
We will trace the history of ideas about optic nerve anatomy and function in the Western world from the ancient Greeks to the early 20th century and show how these influenced causal theories of optic nerve diseases. Greek and Roman humoral physiology needed a hollow optic nerve, the obstruction of which prevented the flow of visual spirit to and from the brain and resulted in blindness. Medieval physicians understood that the presence of a fixed dilated pupil indicated optic nerve obstruction, preventing the passage of visual spirit, and that cataract surgery in such cases would not restore sight. During the Renaissance, the organ of vision was transferred from the lens to the optic nerve, which was generally believed to be on the axis of the eye. The acuity of central vision (at the optic disc) was explained by the concentration of visual spirit where the optic nerve met the retina.

The growth of anatomy and influence of mechanical philosophy from the 17th century led to visual spirit being replaced with the concept of nerve force, which later became associated with electricity travelling along nerve fibres. This coincided with discourse about the nature of the nervous system and a shift in orientation from understanding illness holistically in terms of an individual's humoral imbalance to the concept of organ-based diseases. Both the microscope and the ophthalmoscope allowed visualisation of the optic nerve, but problems of interpretation persisted until conceptual transformations in medical science were made. Eye (2004) 18, 1096-1109. doi:10.1038/sj.eye.6701578
\end{abstract}

${ }^{1}$ Wellcome Trust Centre for the History of Medicine University College London London, UK

2Paediatric Ophthalmology Institute of Child Health University College London London, UK

Correspondence: C Reeves 192 Sheen Court Richmond Surrey TW10 5DH, UK Tel: + 442088780841 E-mail: carole.reeves@ dial.pipex.com

Received: 4 September 2003

Accepted: 4 September 2003

The authors have no proprietary interests or research funding relating to this publication.
Keywords: history of medicine; optic nerve; optic nerve diseases
The optic nerve through history

\section{Introduction}

The history of concepts of nerve function is one of the longest in the evolution of the neurosciences although Clarke and Jacyna ${ }^{1}$ suggest that it falls naturally into three epochs. The first was prior to Luigi Galvani's (17371798) theory of animal electricity (galvanism), published in $1791 .^{2}$ The second encompassed the period 1791 to the 1840 s when the nature of galvanism and its role in nerve conduction was studied. The third began during the 1840s when Emil du Bois-Reymond (1818-1896) established the discipline of electrophysiology as a laboratory science. We might now add a fourth - a very recent 'modern' era, which includes imaging, biochemistry, and molecular genetics.

It is easy to give the impression from the safety of our modern era view, armed with hindsight, that we know better than our ancestors but this is not the case: we know differently but just as impermanently as they did. 'If I have seen further, it is by standing on the shoulders of giants,' was Isaac Newton's modest way of explaining his genius to Robert Hooke in 1676.

\section{Greek ideas and the influence of Galen}

From c.300. BCE to the early 19th century, the most consistent theory of nerve function involved impressions travelling along the lumen of a hollow nerve carried by some material substance, which varied through the centuries from an ethereal pneuma or spirit to a subtle, imponderable fluid. According to the Greek physician,Galen (CE 129-c.216), whose influence on anatomy prevailed in the Western world until the 16th century, nerve 'channels' were described by Herophilus (c.330-260 BCE) ${ }^{3}$ and Erasistratus (c.330-255 BCE), ${ }^{4}$ the first documented human anatomists who taught in Hellenistic Alexandria. ${ }^{5}$ 
Galen, who practiced only animal dissection, accepted the reality of the hollow nerve. In his physiology of the nervous system, psychic pneuma was collected in the ventricles of the brain and distributed through the nerves to all parts of the body to provide them with sensation and motion. ${ }^{3}$ He admitted that cobweb-thin nerves might not possess a lumen but those in the optic nerves (poroi optikoi-optic channels) were large enough to be visible and to be probed with a hog bristle. Their size allowed psychic pneuma to flow in abundance, emerging from the eyes to unite with the incoming light, a process essential for vision., ${ }^{3,6}$ In Galen's model of the eye, the retina was formed by the optic nerve as it broke up and spread out; the retina's rich supply of blood vessels performed a nutritive function since the crystalline humour (lens) was the organ of vision. The optic nerves came together at the chiasma (from the Greek letter $\times$ - chi) in order to produce a single impression in binocular vision but did not interchange. ${ }^{3}$

\section{Medieval ocular anatomy and physiology}

Galen's theory of vision and ocular anatomy passed into the Arab-Islamic world from the late 8th to early 11th centuries, mainly through Christian translators in the ecclesiastical libraries and 'court academies' of Egypt, Syria, and particularly Mesopotamia. One of the most important was Hunain ibn Ishaq (c.809-c.873), whose Kitab al-'ashr maqalat fi l-'ayn (Book of the Ten Treatises on the Eye $)^{7}$ was the chief source through which medieval ophthalmologists in the West obtained their Galen. Ten treatises was influential up to the end of the 16th century and includes the earliest known diagrams depicting the anatomy of the eye (Figure 1). Hunain differentiated between the optic nerves, through which great quantities of psychic pneuma flowed in a steady stream from the brain, and the body's other sensory-motor nerves, which received the 'force' of the pneuma but not the substance itself. The optic nerve, originating in the brain, which was the source of all sensation, was enveloped by both its covering membranes - the pia mater and the dura mater (Figures 2 and 3). ${ }^{7}$ The ocular anatomy of Rhazes (d. 925), Avicenna (d. 1037), and Alhazen (c.965-1038) remained within mainstream Galenism, although Rhazes and Avicenna suggested that the optic nerves might cross in the chiasma, and Alhazen's optical model of vision (Figure 4) provided Johannes Kepler (1571-1630) with the conceptual materials on which to build his theory of the retinal image. ${ }^{6}$

William of Conches (c.1090-c.1154), tutor to Henry Plantagenet, was an important contributor to the revivalist movement in natural sciences, which swept across Western Europe at the turn of the 12th century. Writing almost a thousand years after Galen, he,

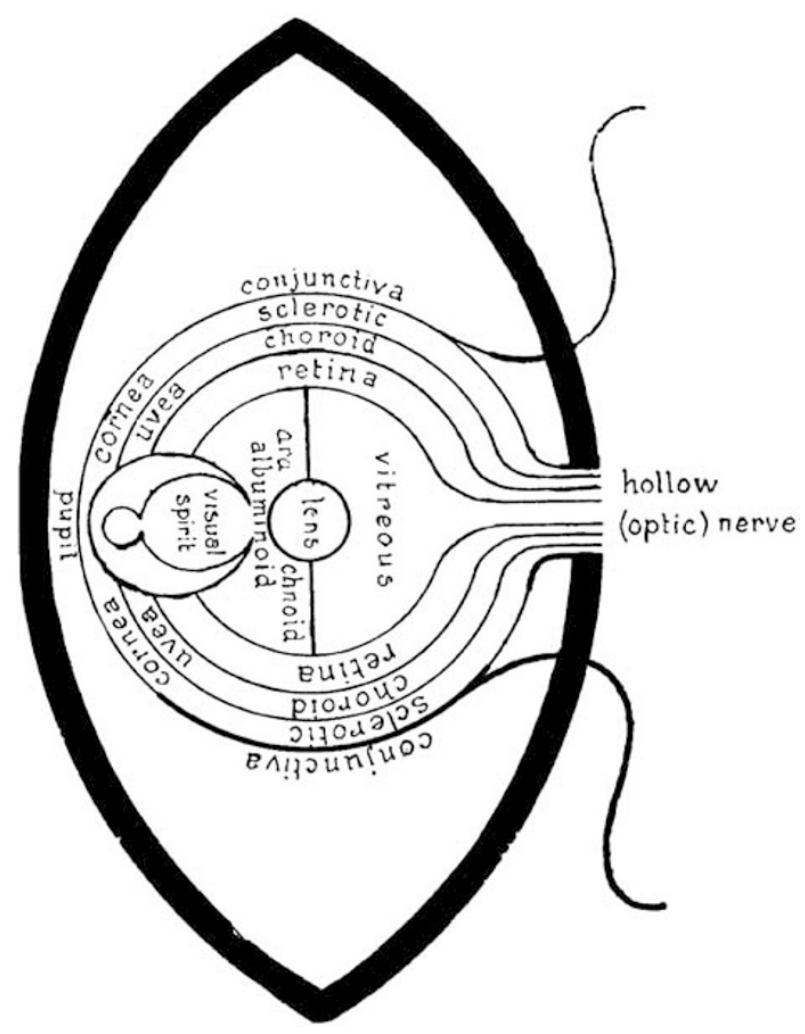

Figure 1 Diagrams depicting Galen's theories of vision and anatomy survive in Arab-Islamic manuscripts such as this of Hunain ibn Ishaq (c.809-c.873). The optic nerve was hollow to transmit psychic pneuma, and the lens was the organ of vision. From Kitâb al-'ashr maqalat fi l-'ayn (Book of the Ten Treatises on the Eye). Wellcome Library, London.

nevertheless, maintained a humoralist interpretation of vision. 'Spiritual virtue', elaborated in the heart, passed through 'thin vessels' to the brain where it was further refined into psychic pneuma by the rete mirabile, the 'marvellous network' of nerves and vessels, which Galen had found at the base of the brain in ungulates and believed existed in humans. ${ }^{8}$ It then travelled through hollow nerves to the organs of sense. When the soul wished to see, it sent forth psychic pneuma through the optic nerves to the eye, which emerged through the pupil, mingling with the external light and extending to the object. Having diffused over the surface of the object, it returned to the soul carrying the visual impression. As proof of this physiological process, William cited the fact that the eye of an observer might itself be corrupted by looking at a diseased eye since the blight would be carried back on the psychic pneuma. The phenomenon of the 'evil eye' worked in a similar manner. A glance from an individual of a 'distempered' disposition was harmful because that person sent forth a 'distempered beam $^{\prime 9}$ (Figure 5). The evil eye became embedded into 


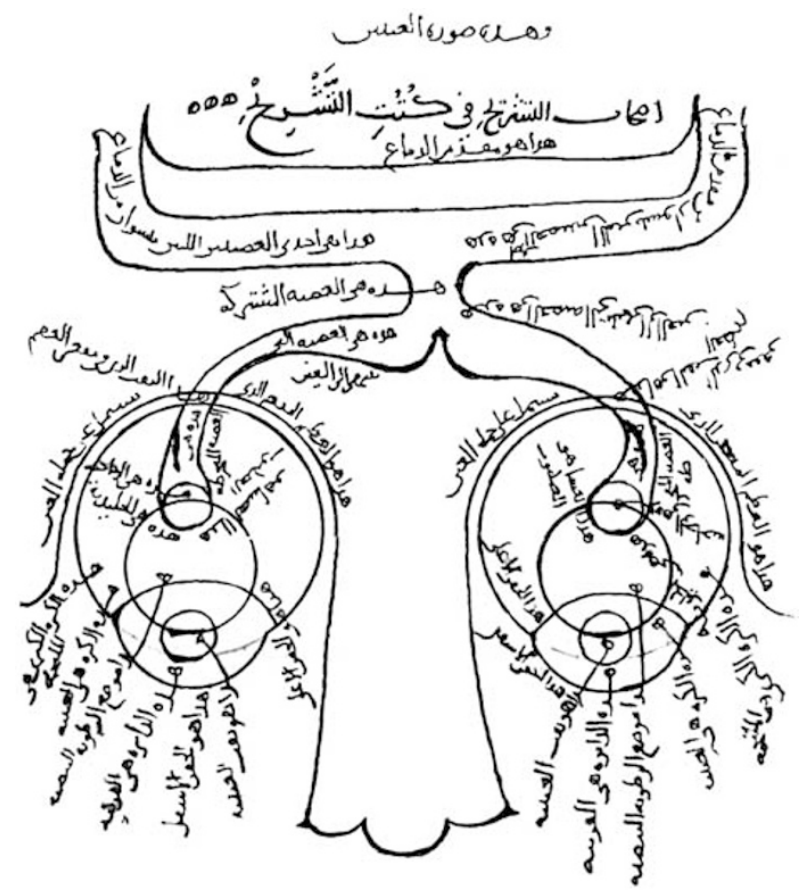

Figure 2 Diagram from Kitâb al-manâzir (Book of Optics) by Ibn al-Haitham (Alhazen, c.965-1038), showing a chiasm-'the joining nerve'. The Sulimaniye Library (Fatih Collection), Istanbul, with kind permission. Professor MS and Dr M Ogüt kindly obtained this image.

folklore and survives as a superstitious belief in communities today.

By the end of the 13th century, which coincided with the growth of the medical schools in Europe, textual synthesis from early ophthalmological sources had reached a high level of sophistication through scholars such as Gilbertus Anglicus, William of Saliceto, and Lanfranc of Milan. But, as Laurence Eldredge has noted, their impressive achievement remains a mastery of texts, not of anatomy itself. ${ }^{10}$

\section{The Renaissance and early modern Europe}

The European social and cultural Renaissance from the 14 th to the end of the 16th centuries was concerned with the search for truth, both in the written word through the resurrection of original sources (in medicine, these were mainly the Greek texts of Hippocrates and Galen) ${ }^{11,12}$ and by direct observation. Andreas Vesalius (1514-1564)

(Figure 6), the influential Belgian anatomist teaching in Padua, was among the first to doubt the presence of Galen's optic nerve channel, having searched for it in dogs both living and dead, in larger animals, and in a man just beheaded. ${ }^{13}$ Nevertheless, so strong was Galen's hold on anatomy that Vesalius did not deny the hollowness of nerves and, indeed, the issue hotly

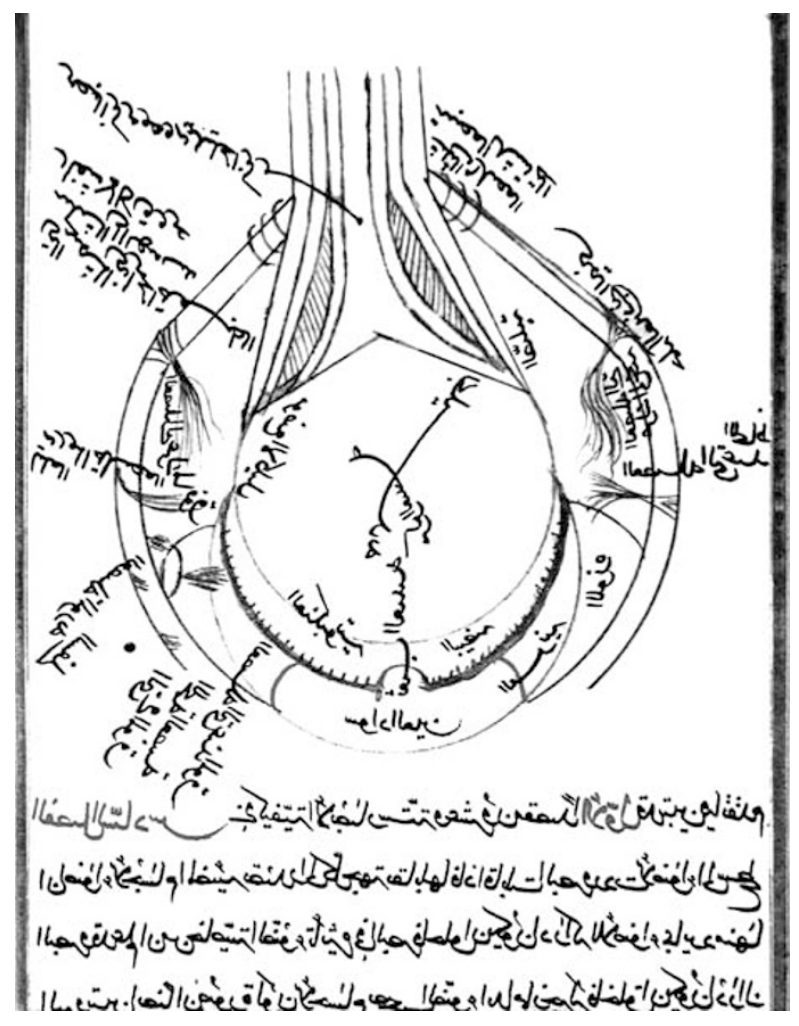

Figure 3 From Kamâl al-dîn Abu'l-Hasan al-Fârîsi (1668). The lens, as the organ of vision, is represented by the large central area; the hollow optic nerve permits the flow of psychic pneuma. The Sulimaniye Library (Ayasofia Collection), Istanbul, with kind permission. Professor MS and Dr M Ogüt kindly obtained this image.

debated was the primacy of observation over knowledge of causes, the latter being the traditional discourse of the philosophers. Detractors of the 'anatomia sensata' ${ }^{14}$ held that true knowledge of a part rested as much on a knowledge of its function or purpose as on its structure (Figure 7). A few others such as Jean Riolan the Elder (c.1538-1605) in Paris accepted that Nature, God's regent in the world, had generated changes in the human body since Galen's time and was still doing so. Vesalius' successors, Gabrielle Fallopia (1523-1563) ${ }^{15}$ and Volcher Coiter (1534-c.1600), ${ }^{16}$ not only questioned the existence of nerve channels but from observation began to speak of the composition of nerves in terms of 'fibres' (Figure 8). However, since the model of the nerve remained that of a structure through which a substance flowed back and forth, these fibres were either hollow or porous.

Constanzo Varolio (1543-1575) of Bologna was the first to dissect the brain from below and to show in annotated detail the structure of the optic nerve in its relation to the central nervous system. ${ }^{17}$ René Descartes' (1596-1650) model of the optic nerve was a tube enclosing bundles of smaller tubes that contained 'many very fine threads 


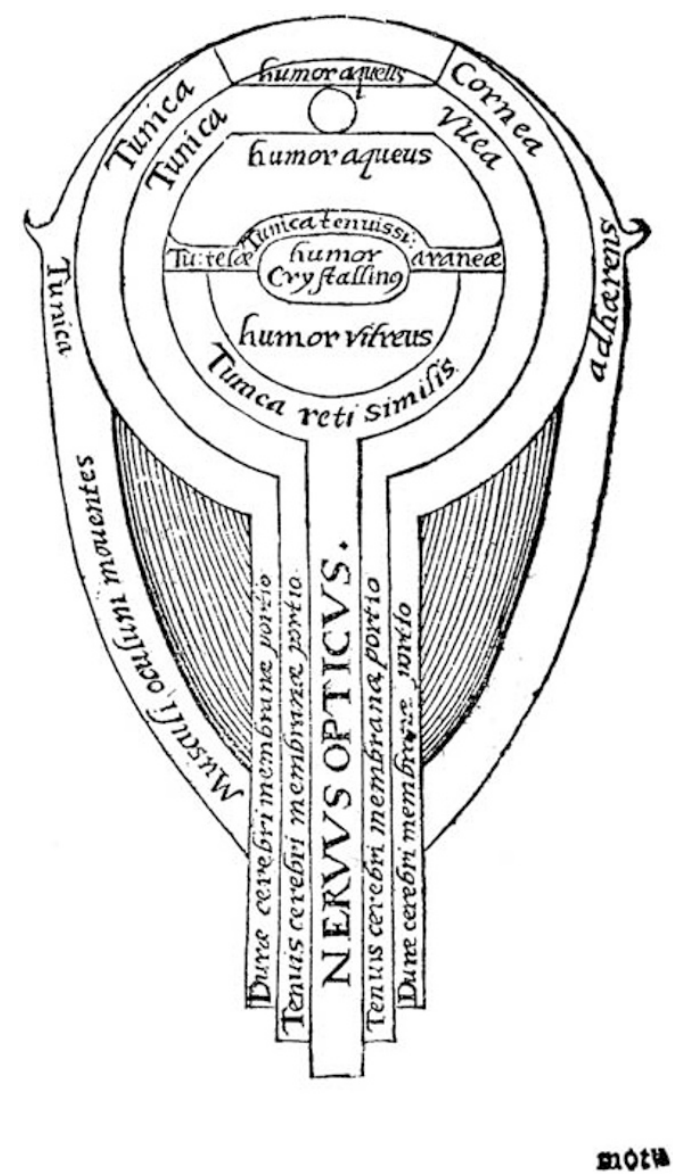

Figure 4 The eye according to Ibn al-Haitham (Alhazen, c. 9651038). From Opticae thesaurus Alhazeni Arabis ...(1572). Wellcome Library, London.

which come from the substance of the brain itself ${ }^{18}$ (Figure 9). Animal spirits, released from the sensorium commune, which he located within the pineal gland, flowed through the little tubes between the threads. This concept was demonstrated microscopically in 1717 by the Dutch microscopist Antoni van Leeuwenhoek (1632-1723), whose illustration of a peripheral nerve showed a bundle of myelinated axons surrounded by the myelin sheath (Figure 10). Leeuwenhoek interpreted the axon, represented as a slit in the centre of each fibre, as a channel that had collapsed following the escape of 'a very fluid humour' ${ }^{19}$ Being unable to discern Galen's channels in bovine optic nerves (Figure 11) but understanding that some communication had to pass to and from the eye, Leeuwenhoek, 40 years earlier, had proposed a mechanical theory of vision whereby a viewed object set in motion 'globuls' at the proximal ends of the nerves, carrying its impression to the brain like ripples through water. ${ }^{20}$ Isaac Newton's (1642-1727) mechanical model of nerve action, using the 'vibrating motion' of an aetherial medium, had no need for a

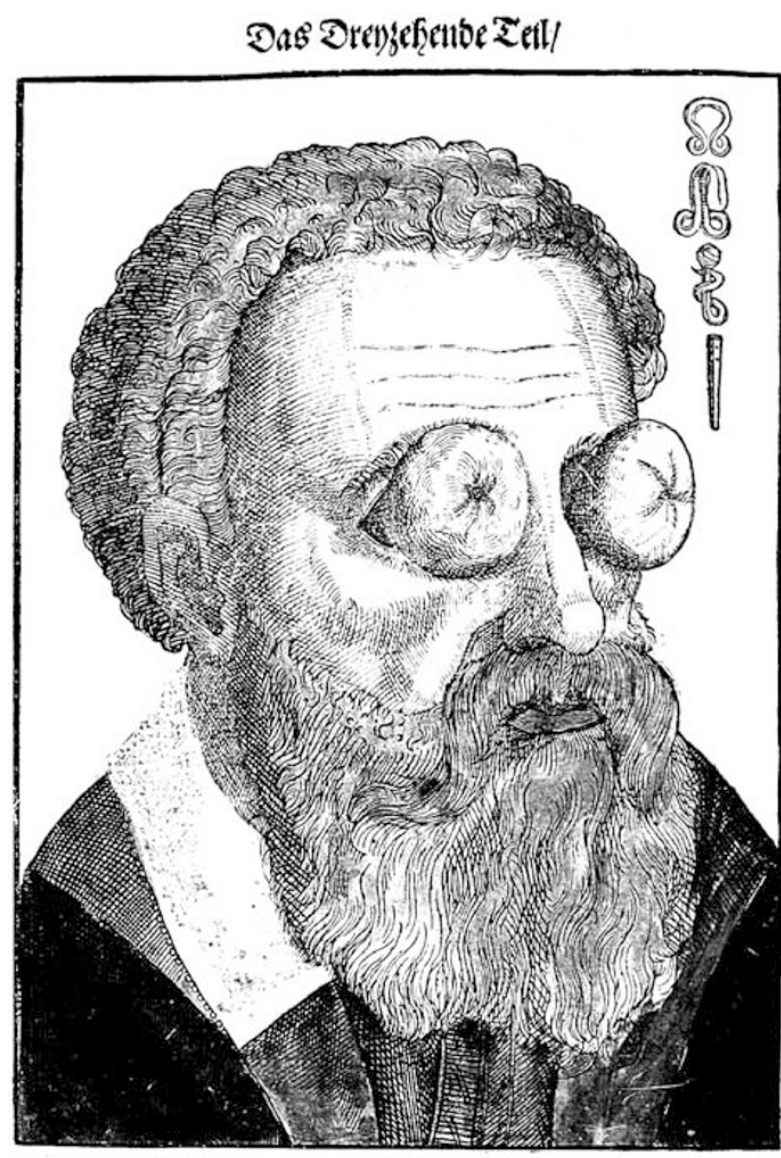

23er fan ober mag nun fagen / oas folches folte won 2hotur

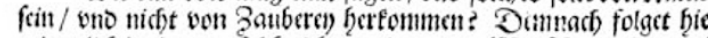

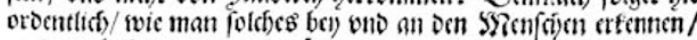
curiren, fyeiten oder foenoen fol.

EB \{ vitD

Figure 5 A man blighted by a glance from a person with the evil eye. From Georg Bartisch. Ophthalmodouleia ... (1583). Wellcome Library, London.

hollow nerve. Aether, excited in the eye by light rays, was 'propagated through the solid, pellucid and uniform Capillamenta (hair-like fibres) of the Optick Nerves into the place of Sensation'. ${ }^{21,22}$

Meanwhile, a Swiss physician, Felix Platter

(1536-1614), had shifted Galen's organ of vision from the lens to the optic nerve and its 'expansion' in the eyeball (the retina). He supposed that 'species and colours of external objects' were presented to the optic nerve by the lens, which acted as its 'looking glass' ${ }^{23}$ The entrance of the optic nerve into the eye was generally believed to be on the axis rather than to its nasal side. Vesalius had understood its correct anatomy, ${ }^{13}$ but his illustrations depict axial attachment, and Kepler's optical model of vision was based on this anatomical premise. In Kepler's understanding, the acuity of central vision (at the optic disc) could be explained by the concentration of visual spirit where the optic nerve met the retina. 'From that 




Figure 6 Andreas Vesalius (1515-1564), a Belgian who, in 1537, was appointed as a lecturer in surgery and anatomy at the University of Padua. Oil painting after a woodcut. Wellcome Library, London.

point', he wrote, 'It is spread out over the sphere of the retina; and as it departs from its source it also becomes weaker'. ${ }^{24}$

\section{The discovery of the blind spot}

The off-axis attachment of the optic nerve was illustrated for the first time in 1619 by the German mathematician Christoph Scheiner (1575-1650), ${ }^{25}$ but there is no evidence that this influenced a change in understanding of the anatomical location of central vision (Figure 12).

Indeed, in 1668, Edme Mariotte (1620-1684) encountered considerable opposition following his announcement of the discovery of a non-seeing area in the eye corresponding to the head of the optic nerve, and from which he deduced that it entered the eye at a point nearer the nose than the optical axis. ${ }^{26}$

There was much physiological and philosophical discussion concerning the imperceptibility or 'filling-in' of the blind spot, which continued well into the 19th century. Robert Bentley Todd (1809-1860) and William Bowman (1816-1892) offered the obvious explanation but

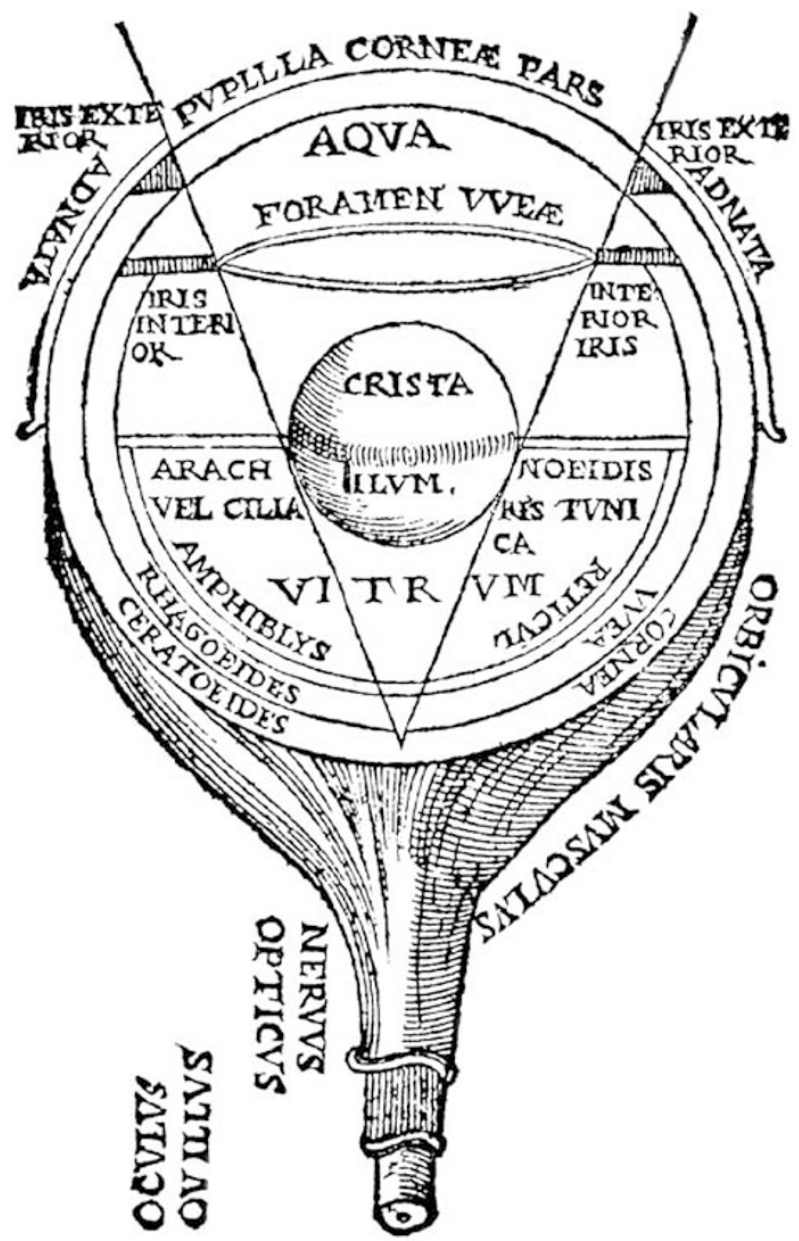

Figure 7 The eye with its hollow optic nerve as depicted by Cornelius Gemma (1535-1579), Professor of Medicine at the University of Louvain. From De arte cyclognomica ... tomi III (1569). Wellcome Library, London.

one that had been surprisingly difficult to grasp: 'If the blind spot had been situated in the axis, a blank space would have always existed in the centre of the field of vision, since the axis of the eyes, in vision, are made to correspond. But ... the blind spots do not correspond when the eyes are directed to the same object, and hence the blank, which one eye would present, is filled up by the opposite one'. ${ }^{27}$

Experienced doctors such as the surgeon-anatomist William Cheselden (1688-1752) recognised the potential hazards of a blind spot in an only eye. He related the unfortunate tale of 'a gentleman, who having lost one eye by the smallpox', walked through a hedge in which 'a thorn unseen ... struck the other and put it out'. ${ }^{28}$

In 1870, the German-American ophthalmologist Hermann Knapp (1832-1911), who had been Albrecht von Graefe's (1828-1870) assistant in Berlin, demonstrated an enlargement of the blind spot in patients with 'choked disc'. ${ }^{29}$ Von Graefe had introduced 


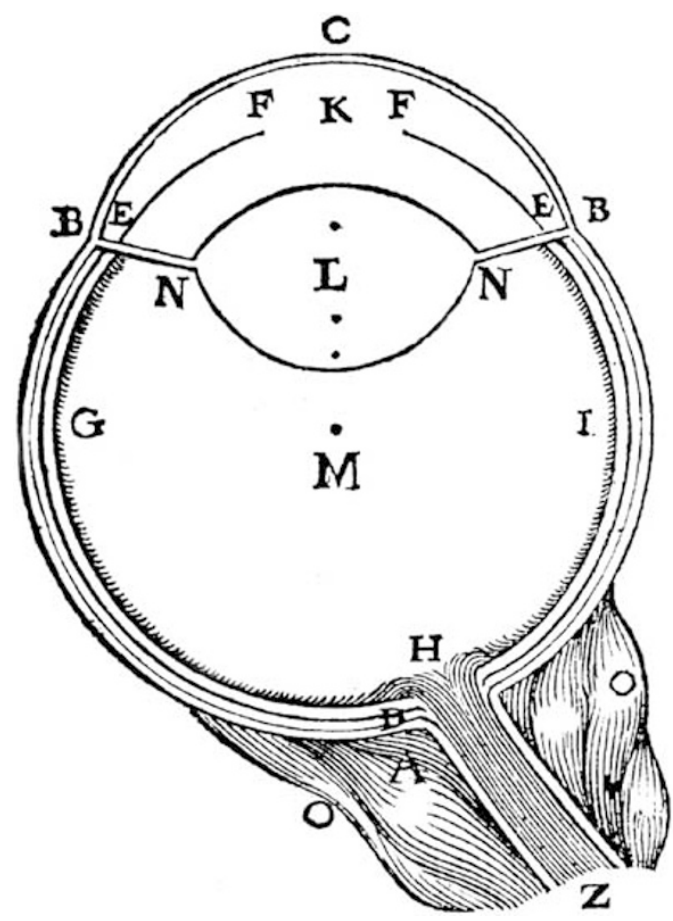

Figure 8 René Descartes' (1596-1650) model of the eye with the optic nerve composed of fibres. From Discours de la methode pour bien conduire sa raison ... (1637). Wellcome Library, London.

the examination of the visual field into clinical practice and, initially, it was the blind spot and not the fixation point that was employed as zero on the chart. ${ }^{30}$

\section{The 18th century}

By the 18th century, most investigators had exchanged the concept of an aetherial spirit for a subtle nerve fluid or nerve force to explain nerve function. Albrecht von Haller (1708-1777), the outstanding Swiss physiologist, postulated a vis nervosa or motor force originating from the brain that resided in the nerves. ${ }^{31}$ Although he was largely concerned with the action of motor nerves, vis nervosa as an abstract force was applied to the messaging system of sensory nerves by a number of researchers including JA Unzer (1727-1799), George Procháska (1749-1820), ${ }^{32}$ and Marshall Hall (1790-1857), the last of whom was still using it in $1840 .{ }^{33}$

The idea of a vis nervosa being electrical in nature, although rejected by Haller, was popularised following the invention, in 1745, of the Leyden jar, and through investigations of electric fish by a number of respected scientists including John Hunter (1728-1793), ${ }^{34}$ Henry Cavendish (1731-1810), ${ }^{35}$ Alexander von Humboldt (1769-1859), ${ }^{36}$ and Humphry Davy (1778-1820). ${ }^{37}$

While the nature of the messaging system was being debated, Haller's student Johann Gottfried Zinn (17271759) helped demolish the theory of the hollow optic

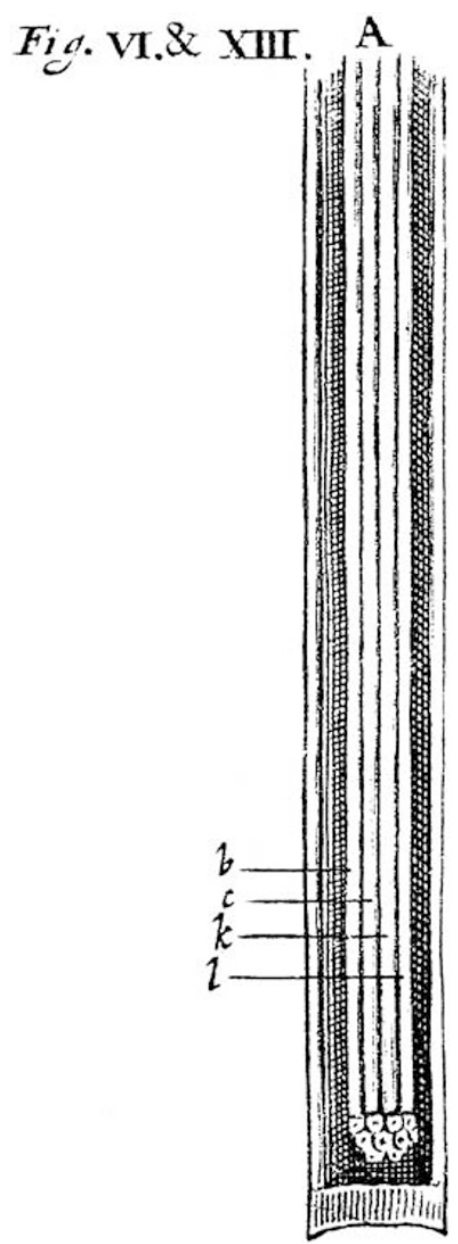

Figure 9 Descartes' concept of the optic nerve was a tube enclosing bundles of smaller tubes that contained 'many very fine threads which come from the substance of the brain itself'. From De homine ... (1662). Wellcome Library, London.

nerve in his seminal atlas Descriptio anatomica oculi humani (1755). ${ }^{38}$ Cheselden, describing the microscopic appearance of sectioned nerves as 'so many small distinct threads running parallel, without any cavity observable in them', offered an explanation for the persistence of the concept by suggesting that, 'some incautious observers [had mistaken] the cut orifices of the arterious and venous vessels ... for nervous tubes'.28

\section{The 19th and early 20th centuries: Galvanic theories}

Galvani's proposal, in 1791, that the nervous system was, in fact, a generator of electricity, was instrumental in sweeping away the theories of nerve action postulating nerve spirits or fluid and establishing a framework for future investigation into electricity and nerve function. He believed that animal electricity was 'electrical fluid ... secreted from the cortical substance of the brain' and probably extracted from blood. ${ }^{2}$ By the 1830 s, with the 


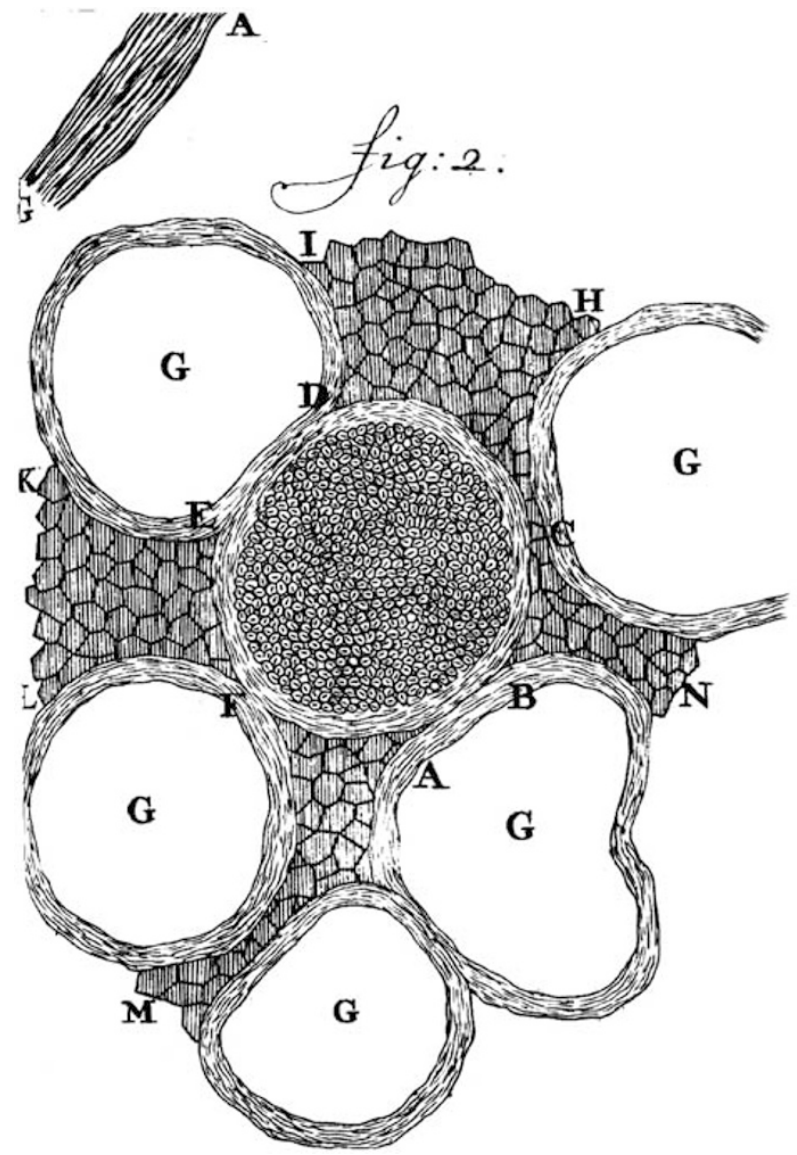

Figure 10 The Dutch microscopist Antoni van Leeuwenhoek (1632-1723) depicted the axon as a slit in the centre of each fibre - a channel that had collapsed following the escape of 'a very fluid humour'. From Epistolae physiologicae super compluribus naturae arcanis ... (1719). Wellcome Library, London.

development of more sensitive electrophysiological measuring devices than had been available to Galvani, influential physiologists such as François Achille Longet (1811-1871) and Johannes Müller (1801-1858), who examined the optic nerves and chiasmas in a variety of species, ${ }^{39}$ were suggesting that electricity was merely the stimulus that set in motion a 'nerve principle'.

Although its nature was unknown, the nerve principle was actually the conduction mechanism. Müller admitted that he had never been able to detect an electric current in nerves but believed that 'in the eye, a feeble galvanic current excites the special sensation of the optic nerve, namely, the sensation of light'. It was Müller's student, Emil du Bois-Reymond (1818-1896), who in 1843 , showed conclusively that electrical currents were present in nerves ${ }^{40}$ and went on to propose that the electrical signals, which he could detect using the highly sensitive galvanometers that he invented were the external manifestations of the underlying, but unknown, conduction mechanism. By the late 1860s, he was ready

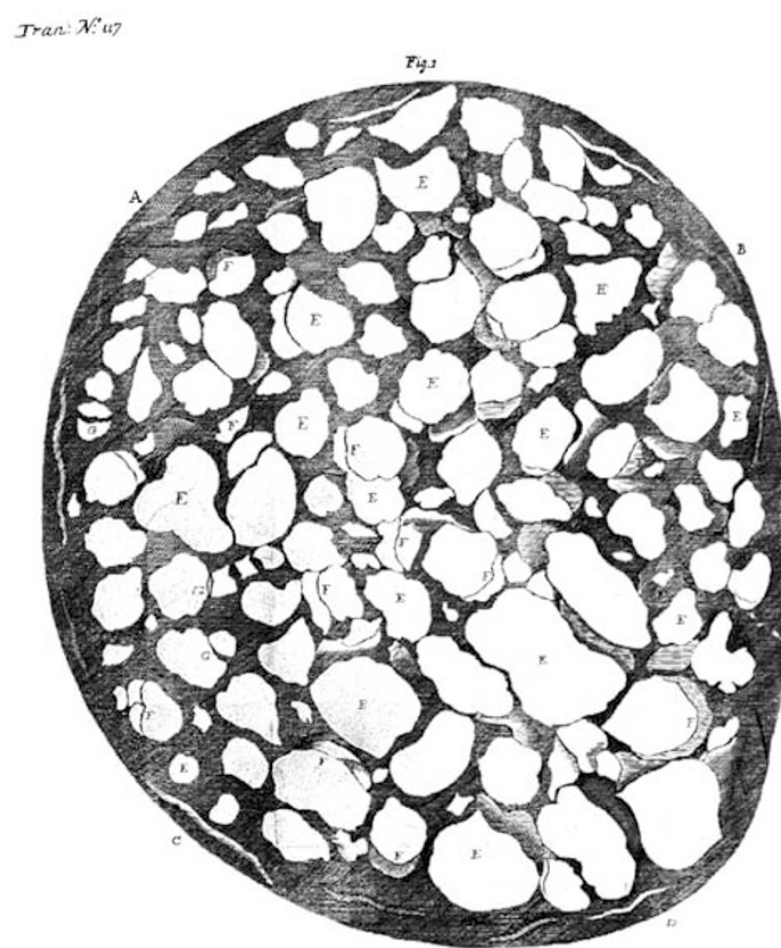

Figure 11 Van Leeuwenhoek could not find Galen's optic nerve channels but, knowing that there had to be communication between the eye and the brain, proposed that vision set 'globuls' in motion in the optic nerve. Transverse section of bovine optic nerve (1674), from The Collected Letters of Antonie van Leeuwenhoek, Vol 1 (1939). Wellcome Library, London.

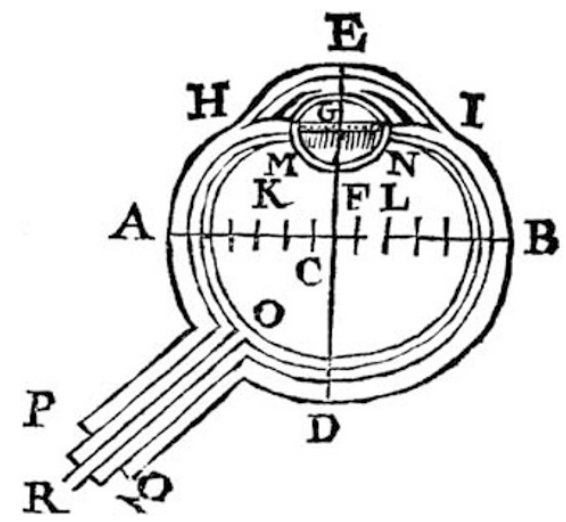

Figure 12 Christoph Scheiner (1575-1650), a German mathematician, was the first to illustrate (in 1619) the off-axis attachment of the optic nerve, and also verified experimentally Johannes Kepler's theory of the retinal image. From Oculus. Hoc est ... (1652). Wellcome Library, London.

to speculate that this conduction mechanism was 'some internal motion, perhaps even some chemical change, of the substance itself contained in the nerve tubes,

spreading along the tubes ... both ways from any point where the equilibrium has been disturbed ...'. He did 
not deny that electricity played a part in 'the internal mechanism of the nerves'.

Most physiological, and virtually all electrophysiological research, during the mid-19th century was carried out in Europe, notably Germany and Italy. In Britain, where the investigative tradition was anatomical rather than physiological, Todd and Bowman remained locked into discussions about the source of animal electricity and whether 'nervous force' was analogous to current electricity. They finally opted for the idea of it being 'a power developed in the nervous structure under the influence of appropriate stimuli' ${ }^{27}$ The analogy between animal electricity in a nerve and a current of Voltaic electricity flowing along a conducting wire was commonly made by early investigators but shown to be erroneous in 1850 by Hermann Helmholtz (1821-1894) who measured the speed of nerve conduction and found that it was slower than current electricity. ${ }^{41-43}$ Ludimar Hermann (1838-1914), a student of du Bois-Reymond, first demonstrated that, unlike current electricity in a wire, the nerve's motive principle was a self-propagating wave of negativity that advanced in segments along it, although he was unable to explain how it was transmitted from segment to segment. ${ }^{42,44}$

These were the beginnings of our present notion of nerve function but it was not until the 20th century that Edgar D Adrian (1889-1977) and his team revealed that the conduction signal resulted from the transfer of ions across the membrane of a nerve fibre, which sent a wave of depolarisation or action potential along the axon. ${ }^{45}$ Adrian concluded that: '...there are no radical differences in the messages from different kinds of sense organs or different parts of the brain. Impulses travelling to the brain in the fibres of the auditory nerves make us hear sounds, and impulses of the same kind ... in the optic nerve make us see sights. The mental result must differ because a different part of the brain receives the message and not because the message has a different form' ${ }^{46}$

\section{The microscope and development of histology}

Despite van Leeuwenhoek's (Figure 13) spectacular microscopical observations at magnifications up to $\times 400$, his results were largely unrepeatable because he was uniquely skilled in lens-grinding and did not make public the details of his instruments. Following his death in 1723, there was little scientific use of the microscope until Joseph Jackson Lister (1786-1869) developed the achromatic objective during the 1820s. Thereafter, much of the pioneering microscopy that led to the elucidation of cell theory was carried out in Germany by workers such as Johannes Müller (1801-1858), Matthias Jakob Schleiden (1804-1881), Theodor Schwann (1810-1882),

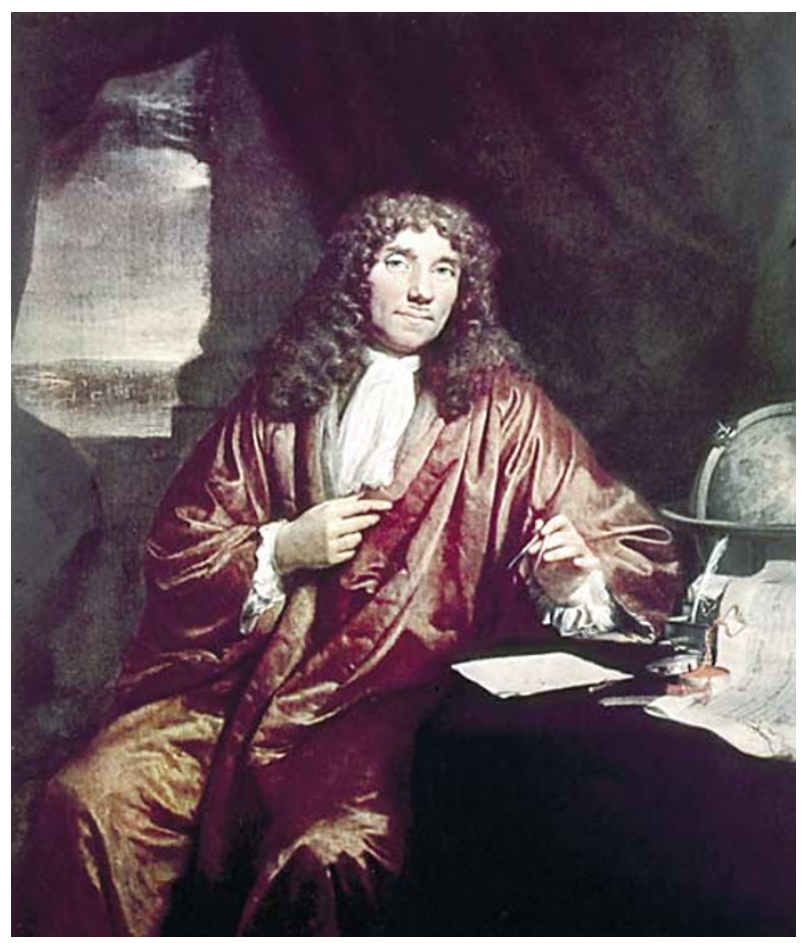

Figure 13 Antoni van Leeuwenhoek, a draper from Delft, hand-made his own microscopes, which have powers of up to $\times 400$. After his death, microscopes were little used in science until Joseph Jackson Lister (1786-1869), father of Joseph Lister, developed the achromatic objective in the 1820s. Oil painting by J Verolje. Wellcome Library, London.

and Rudolf Virchow (1821-1902). Tissues of the eye and nervous system, among the most difficult to prepare and interpret, were subject to novel staining techniques by Jan Evangelista Purkinje (1787-1869) ${ }^{47}$ Albert von Kölliker (1817-1905), ${ }^{48}$ Louis Ranvier (1835-1922), ${ }^{49}$ Camillo Golgi (1843-1926), ${ }^{50,51}$ and Santiago Ramón y Cajal (1852-1934). ${ }^{52}$

Salomon Stricker (1834-1898) wrote Manual of Human and Comparative Histology (1869-1872), which was translated into English as the volumes were published. ${ }^{53}$ The third volume included contributions from 10 histologists writing on the eye alone. It could be shown, for the first time, that optic nerve fibres and ganglion cells were diminished in diseases such as glaucoma. One of the first eye histology atlases, Atlas of the pathological anatomy of the eyeball (1875), by two German ophthalmologists, Ernst Hermann Pagenstecher (18441932) and Karl Philipp Genth (1844-1904), was translated into English by William Gowers (1845-1915). ${ }^{54}$ The authors avoided high-magnification microscopy because, at this period in the history of microscopy, clinicians were generally more interested in topographical histology than in acquiring knowledge of what was going on in individual cells. Like all novel investigative techniques, 
interpretation required the assimilation of conceptual changes.

\section{The ophthalmoscope}

The introduction of the ophthalmoscope by Helmholtz in 1851 also made it necessary for ophthalmologists to learn to perceive and interpret what they saw through the instrument. Edward Greely Loring (1837-1888) of New York believed that in the whole history of medicine there is no more beautiful episode than the invention of the ophthalmoscope ... by its means we are able to look upon the only nerve in the whole body which can ever lie open to our inspection under physiological conditions ... ${ }^{55}$ Exciting times, indeed, and it is fascinating to realise just how observant the ophthalmoscopists of that era were, despite their simple instruments and weak illumination. Nevertheless, misinterpretation of the ophthalmoscopic appearance of the optic nerve could and did influence ideas about the cause of eye diseases.

\section{History of ideas about optic nerve diseases}

\section{Introduction}

In the Western world, the medical tradition, until at least the 18th century, explained disease largely in terms of an imbalance in the body's qualities, humours, or temperaments. External factors such as environment, diet, behaviour, and injury affected patients in different ways according to their individual susceptibility, and doctors tailored therapies to suit each patient.

The 18th and 19th centuries witnessed an orientation towards the concept of organ-based disease, which George Rosen has suggested was essential for the development and acceptance of the ophthalmoscope as a diagnostic tool. ${ }^{56}$ At all periods, however, explanations for the symptoms and signs of disease have been based on anatomical and physiological beliefs.

\section{Humoral ideas about optic nerve obstruction}

For Hunain ibn Ishaq, proof that psychic pneuma flowed from the brain through the optic nerves into the eyes could be observed by shutting one eye, whereupon the pupil of the other became enlarged to allow the escape of diverted pneuma. When the closed eye was opened, the enlarged pupil returned to normal size. ${ }^{7}$ He thus reasoned that if the pupil did not enlarge when one eye was shut, the power of vision was destroyed at its source through an obstruction in the optic nerve, which prevented the passage of pneuma. In such a case, prognosis for restoration of sight was poor. The only intraocular surgery performed at this period (ninth century) was that of couching for cataract and the patency of the optic nerve in the affected eye was used to assess suitability for surgery. (Until the early 18th century, the formation of a cataract was believed to result from the coagulation of a watery humour dropping from some region in the upper eye into an empty space between the cornea and crystalline humour (lens). The object of couching was to remove this coagulated humour and allow the transmission of pneuma. The concept of dislodging a clouded lens was not entertained since this would destroy the organ of vision.) If the pupil dilated when the 'good eye' was shut, it was 'proof that the power of vision [had] been left normal' and that couching might restore it. If it did not dilate, the eye was blind and the operation would not be successful.

Benevenutus Grassus, a much travelled 13th-century Italian oculist, ${ }^{57}$ made the same observations. The presence of a fixed dilated pupil, even in an apparently clear eye, was an indication of optic nerve obstruction and he advised against treatment. Benevenutus and medical practitioners of his day followed the tradition of the Hippocratic physicians whose skill and reputation rested as much on their prognostic talents as their ability to treat and heal. It was better to recognise a case as hopeless than to attempt a remedy and fail. The causes of optic nerve obstruction were those that filled the head with vapours and included 'excess of youth and insomnia ... worry, anguish, crying and confusion in the head ... too hard work, too much sexual intercourse, and too much reading and writing' ${ }^{58,59}$ By the end of the 16th century, the English physician Walter Bayley recommended combing the hair every morning to 'draweth the vapours out of the head, and removeth them from the sight'. ${ }^{60}$

This model of physiology, disease theory, and treatment profile was still being offered at the turn of the 18th century by Sir William Read (d. c.1715), an itinerant mountebank who became oculist-in-ordinary to Queen Anne. ${ }^{61} \mathrm{He}$ accepted that in amaurosis of rapid onset, the 'spirit of sight' conveyed through the hollow optic nerve could be blocked by 'gross slimy humours', or the nerve itself might collapse from the weight of excess humours pressing on it externally. His explanation for the phenomenon of consensual reflex was identical to that of his predecessors as were the causes of optic nerve obstruction: '... ill digestion, drinking of hot wine, great heat of the sun or cold on the head, continual reading, bathes after meat, vomiting, immoderate company with women [and] holding in of the breath, as we see in trumpeters' ${ }^{62}$ Prior to the onset of blindness, the patient might experience a great heaviness in the head and eyes, consistent with an overabundance of humours for which traditional remedies included bloodletting, cupping, scarifying, purging, and attention to diet. Eye salves were 
considered useless since the fault was systemic and not localised to the eye.

These examples spread over eight centuries, were characteristic of a system belief that endured until the mid-18th century when, for the first time, a few remarkable clinicians began to perform autopsies on a grand scale and to relate their pathological findings to signs and symptoms of disease during life.

\section{Giovanni Morgagni and optic nerve compression}

Giovanni Battista Morgagni (1682-1771), professor of anatomy at Padua, and a physician of great renown, used the experience gained from some 700 autopsies $^{63}$ in his consultations by correspondence. Consider this letter, dated 1744, from a 49-year-old Dominican priest of 'sanguine habitus' that accompanied his doctor's report: 'At the beginning of my illness I saw what looked like a spark of fire, which went on glittering before my [right] eye. Then I remained with a sort of little cloud which keeps turning in front of it, and the brighter things are the more it can be seen. After having slept, I feel as if the eye were larger and more imbued with fluids, and it always keeps discharging some kind of matter. I can even see objects at a certain distance, but they are blurred; at a very short distance I can make out persons and read a few words, but only in large script' ${ }^{64}$

Morgagni diagnosed 'an incomplete amaurosis' or Gutta Serena (translated in this edition as glaucoma), which he attributed to 'compression of the optic nerve or ... the retina' by dilated varicose blood vessels within these structures due to the patient's overabundance of circulating blood (despite bloodletting). His autopsy experience had shown that optic nerve compression by tumours, fungous excrescences, hydatid cysts, and hydrocephalus might result in blindness, and noted one instance where the optic nerve of a blind eye was 'more slender' than its counterpart as well as being discoloured from the orbit to its origin in the brain (an observation made by Vesalius). He also followed Vesalius in believing that there was no 'decussation of substance' at the chiasma, which explained why both eyes were not necessarily affected in optic nerve disease. However, since it was impossible to restore dilated blood vessels to their normal diameter, treatment of incomplete amaurosis aimed at halting its progress and keeping the other eye healthy. Morgagni's case notes show that he stood in both camps as far as explaining disease in terms of humoral and mechanical philosophy. Commenting upon the unfortunate priest's visions of fire, he maintained that this was a direct result of a distensive force moving the eye's visual fibres as they might be 'moved by a blow on the eyes'. However, the fact that symptoms first occurred in July demonstrated that it was summer's heat expanding the excess blood in vessels that caused them to dilate.

\section{The nervous system and concept of sympathy}

Despite a growing orientation towards organ-based disease and a vision of the body governed by universal laws of matter in motion, neither Morgagni nor his followers departed from holistic treatments, and physicians throughout the West accepted that there was a sympathetic connection between organs. The retina and optic nerve had particular sympathies with the uterus and the alimentary canal. ${ }^{65,66}$ Morgagni's countryman Antonio Scarpa (1752-1832) believed that imperfect amaurosis ... [was] most frequently derived from a morbid excitement or irritation in the digestive organs, either alone or accompanied with general nervous debility, in which the eyes participate sympathetically' by being 'rendered torpid'. ${ }^{67} \mathrm{He}$ was writing at a time of discourse about the nervous system and its role in the disease process. The idea that nerves themselves could become weak, feeble, or flaccid engaged the attention of physicians who changed the focus of humoralism to talk of 'nervous debility' and 'nervous energy'. It was believed that the body had a finite amount of nervous energy, the rapid and imprudent dissipation of which undermined the nervous structures. The passions, too, were moved from the heart to the nervous system, which led Scarpa to make the observation that 'deep grief and terror' had a direct action on the nerves of the eyes. Treatment regimens aimed at invigorating the entire nervous system as well as rousing the languid action of the optic nerves. Peter Degravers, Professor of Anatomy and Physiology at Edinburgh, suggested that the gutta serena was brought on by 'paralysis of the retina and optic nerve', 68 and Georg Joseph Beer (1763-1821) of Vienna recommended horse-riding, billiards, and cricket to relax the sight after 'extreme tension of the optic nerve'. ${ }^{69}$

The association of blindness with the uterus was related to suppressed menstruation. Within humoral physiology (and since Greek times), menstruation was regarded, along with nose-bleeds and haemorrhoids, as Nature's way of dealing with a plethora of blood, and as such, was a balancing process. Treatment of sight loss in these situations was aimed at inducing menstrual bleeding. Scarpa, for example, applied leeches to the internal surface of the labia and electric shocks from the loins through the pelvis 'in all directions' ${ }^{67}$ Amaurosis associated with menstrual suppression in pregnancy was reported in the 17th century by Werner Rolfinck (15991673) of Jena. In his experience, these women were blind 'as often as they were pregnant' and remained so 'till the time of delivery'. ${ }^{63}$ 
Case studies in which patients were afflicted with sudden sight loss following suppression of other bodily secretions, such as perspiration or pus, were cited in popular ophthalmological textbooks during the first half of the 19th-century. ${ }^{70}$ These same textbooks also related amaurosis to fluid loss such as the one that occurred with salivation during mercury treatment for syphilis, copious spitting from tobacco smoking, and seminal emission from excessive venery or onanism. ${ }^{65}$

\section{Seeing the optic nerve}

The introduction of the ophthalmoscope into clinical practice, hailed as 'the beginning of modern ophthalmology', ${ }^{71}$ did not change ideas overnight. Thomas Clifford Allbutt (1836-1925) of Leeds, writing in 1871 , remarked that the number of physicians who are working with the ophthalmoscope in England may, I believe, be counted upon the fingers of one hand' ${ }^{72}$ For Jabez Hogg (1817-1899), surgeon to Westminster Ophthalmic Hospital, and an early aficionado, the ophthalmoscope enabled the clinician to differentiate between 'sensorial' blindness, which had its seat in the retina, optic nerve, or optic tubercle (disc), and those 'large numbers of cases of amaurosis', which originated not in the eye 'but in the sympathetic irritation excited by diseases of near or remote organs'. These included 'caries in the teeth, excessive indulgence in smoking or chewing tobacco, disordered stomach, bowels, liver, kidney and uterus ${ }^{\prime}{ }^{73}$ In other words, Hogg did not expect to see ocular pathology in these types of diseases despite their well-documented association with sudden loss of sight. This idea was almost certainly rooted in the classification of eye diseases as being either functional or structural. Functional diseases (eg those 'exciting' the eye by sympathetic irritation) expressed their symptoms through altered physiology rather than by alterations in structure, whereas structural (eg sensorial) diseases demonstrated clear structural changes. In the eye, these structural changes manifested as hypertrophy or atrophy.

Early users of the ophthalmoscope were also confronted with the problems of visual interpretation. Eduard Jaeger (1818-1884) of Vienna published the first illustration of a glaucomatous optic disc, which he showed as a swelling relative to the surrounding retina ${ }^{74}$ (Figure 14). The idea of a swollen disc fitted well with an inflammatory aetiology because Jaeger, like his grandfather Georg Beer, believed that glaucoma was an ocular manifestation of 'flying' gout, the quintessential

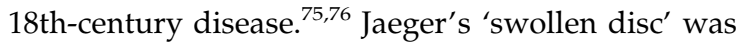
accepted initially by von Graefe who also subscribed to the inflammatory hypothesis, although in his opinion glaucoma was a choroiditis. In a paper published a few months after Jaeger's, he presented a detailed description

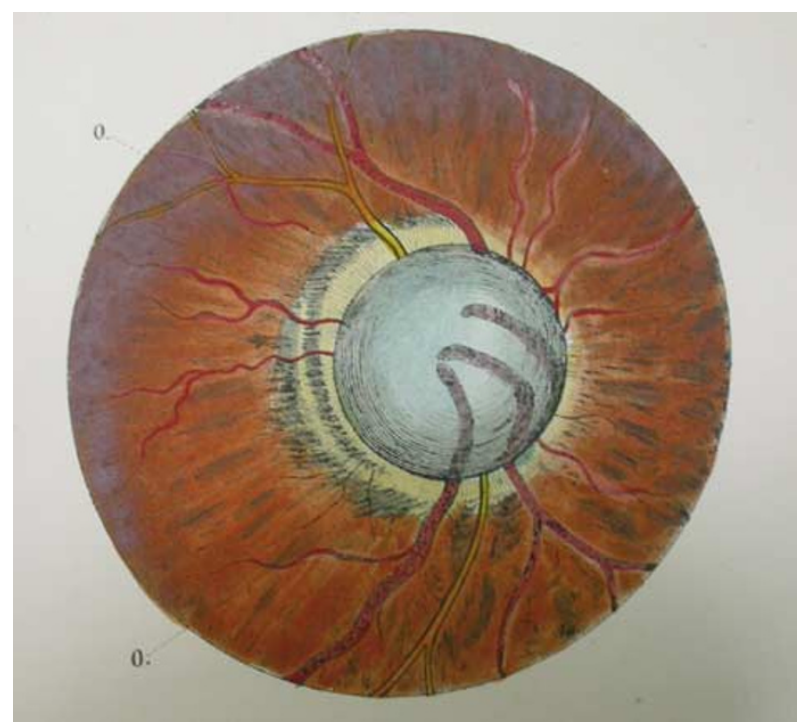

Figure 14 The Viennese ophthalmologist Eduard Jaeger (18181884) perceived the glaucomatous optic disc to be swollen, not cupped, and von Graefe described it as 'a strongly prominent, roundish hill'. Only histopathology caused a reconstruction of the glaucoma disease model. From Jaeger E. Ueber Staar und Staaroperationen (1854): Figure XXXIV, p 103.

of the glaucomatous disc as consisting 'of the nerve entrance in its almost entire circumference [transformed] into a strongly prominent, roundish hill, with only a small ring-shaped sharply outlined peripheral zone remaining in the retinal level. The direction in which the hill is placed upon the retina seems to correspond to the axis of the optic nerve ...' ${ }^{77}$

When histopathology eventually revealed that the 'hill' was, in fact, an excavation, von Graefe and others were obliged to address a number of intellectual problems, not least a reconstruction of the glaucoma disease model. What emerged in von Graefe's case was the lifelong belief that in patients presenting with signs of ocular inflammation and elevated pressure, the inflammation was primary and the increased pressure secondary. Initially, too, there were difficulties of interpretation between what von Graefe termed stauungs-papille, which he defined as a non-inflammatory swelling of the disc caused by increased intracranial pressure, ${ }^{78}$ and the disc appearance illustrative of 'descending neuritis', an inflammation believed to be communicated from the brain through the optic nerves. The ophthalmoscope also revealed certain normal variants of the disc and benign features that could scarcely be differentiated from those indicative of pathology. These observational problems were resolved to a large extent through the reinforcement of visual cues by pathological discoveries. Edward Loring, commenting on Jaeger's misinterpretation of the glaucomatous disc as a prominence, recognised the connection between seeing and understanding. 'Knowing 
that it was an excavation,' he wrote. 'I have never been able to get the effect found and figured by the earlier writers ...' ${ }^{55}$

Within 20 years of the ophthalmoscope's introduction, diseases once believed to cause sight loss by sympathetic irritation were being reclassified either as neurological diseases or as conditions that exerted their primary effect on the nervous system. Allbutt (1871) described the optic atrophy seen in tobacco amaurosis, general paralysis, and Bright's disease; and the optic neuritis associated with lead and mercury poisoning, syphilis, and myelitis. He made the point that it was the exception rather than the rule to find a case of optic neuritis that was not accompanied by cerebral changes. ${ }^{72}$ By the end of the 19 th century, however, the exceptions were still being cited in standard textbooks. They included overuse, exposure to glare, menstrual disorders, and pregnancy. ${ }^{55}$ Ideas about menstrual suppression had not changed for 2000 years. Loring in New York described the case of a 21-year-old woman in whom sudden cessation of the menses 2 years previously had resulted in optic atrophy in the left eye and mild neuritis with central scotoma in the right. Following 'vigorous and systematic leeching and other derivative measures [including] large doses of iron', the menses were reinstated and vision improved. In 1882, he published an account of a 'premature delivery ... performed for the sole object of preserving the sight' in a woman whose three previous pregnancies had been notable for an increasing optic atrophy and left temporal hemianopia. There was no evidence of albuminuria ('Albuminuric retinitis' was recognised as an important cause of blindness during pregnancy ${ }^{79}$ ) and, in all cases, sight had improved following confinement and reappearance of the menses. ${ }^{80}$ He retained the humoral concept 'that what takes place with irregularities of the menstrual flow may also occur in the disturbances of other secretions, such as suppression of the urine or sudden checking of long standing and chronic discharges' ${ }^{55}$

By 1904, Sir William Gowers was suggesting that the ocular and menstrual disturbance in such cases might be 'related to some common cause', ${ }^{78}$ but it was not until Harvey Cushing (1869-1939) clarified the relationships between pituitary tumours and syndromes that the true connection was made. ${ }^{81}$

\section{Conclusion}

The history of the optic nerve and its diseases provides an insight into how conceptual transformations in medicine have been made. A body of ideas accepted and shared by a scientific community becomes the model or 'paradigm' by which it practices and passes on knowledge. Galenic anatomy and physiology is the perfect example of a tradition that solved most medical problems for centuries. The introduction of new observations (eg Vesalian anatomy), theories (nerve force), or tools (the ophthalmoscope) have never been mere additions to existing knowledge because their assimilation requires that knowledge to be challenged, reconstructed, and re-evaluated.

Occasionally, a huge shift in thinking, usually following a period of intellectual crisis, results in a 'scientific revolution' because it reshapes world views. ${ }^{82}$ Kepler's optical model of vision constituted one such revolution, and the emerging paradigm was eventually embraced by all medical practitioners and optical scientists, at least in the West.

Most transitions are modest, often highly specialised, and constitute the usual developmental pattern of mature science although they may result in important conceptual advances. The discovery that pituitary adenomas caused amenorrhoea came from the emerging and productive discipline of endocrinology. These tumours were already known to cause primary optic atrophy and temporal hemianopia due to pressure on the chiasm, ${ }^{78}$ but until their association with amenorrhoea, it was impossible to jettison ancient beliefs, which linked these ocular signs solely to menstrual suppression. We have shown that conceptual transformations in medicine cannot occur unless those who embrace new concepts learn to see things differently.

\section{Acknowledgements}

We thank Dr Anne Hardy and Dr Andrew Wear for reading an earlier version of this paper, and Professor MS and Dr M Ogüt for obtaining Figures 2 and 3.

\section{References}

1 Clarke E, Jacyna LS. Nineteenth-century Origins of Neuroscientific Concepts. University of California Press:Berkeley \& Los Angeles, 1987.

2 Galvani L. De viribus electricitatus in motu musculari commentarius, Facsimile with English translation (Commentary on the effects of electricity on muscular motion). Translated by Margaret Glover Foley with notes and introduction by I Bernard Cohen. Burndy Library: Norwalk, 1953

3 Galen C. On the Usefulness of the Parts of the Body (De usu partium), Translated from the Greek with an introduction and commentary by Margaret Tallmadge May. Cornell University Press: Ithaca, 1968.

4 Galen C. On the natural functions. In: Kühn CG (ed). Medicorum graecorum opera quae extant ... Claudii Galen. C Cnobloch: Leipzig, 1821 p. 97.

5 Longrigg J. Anatomy in Alexandria in the third century BC. Br J Hist Sci 1988; 21: 455-488.

6 Lindberg DC. Theories of Vision from Al-Kindi to Kepler. University of Chicago Press: Chicago \& London, 1976. 
7 Hunain ibn Is-hâq. The Book of the Ten Treatises on the Eye, Publisher: English translation and glossary by Max Meyerhof Government Press: Cairo, 1928.

8 Nutton V. Roman medicine, 250 BC to AD 200. In: Conrad LI, Neve M, Nutton V, Porter R, Wear A (eds). The Western Medical Tradition: 800 BC to AD 1800. Cambridge University Press: Cambridge, 1995 p. 66.

9 William of Conches. A Dialogue on Natural Philosophy (Dragmaticon philosophiae, c.1148). Translated with an introduction by Italo Ronco and Matthew Curr. University of Notre Dame Press: Notre Dame, 1997.

10 Eldredge LM. The anatomy of the eye in the thirteenth century. Micrologus 1997; 5: 145-160.

11 Durling RJ. A chronological census of Renaissance editions and translations of Galen. J Warburg Courtauld Inst 1961; 24: 230-305.

12 Wear A. Knowledge and Practice in English Medicine, 1550-1680. Cambridge University Press: Cambridge, 2000.

13 Vesalius A. On the Fabric of the Human Body (De humani corporis fabrica). Book IV: The Nerves, Translated by William Frank Richardson with John Burd Carman. Norman Publishing: Novato, 2002.

14 Massa N. Liber introductorius anatomiae, siue dissectionis corporis humani.... F Bindoni \& M Pasini: Venice, 1536.

15 Fallopia G. Opera geniuna omnia ... Vol. I: De partibus similaribus. J.A. \& J de Franciscis:Venice, 1606.

16 Coiter V. Observationum anatomicarum chirurgicarumque miscellanea. Externarum et internarum principalium humani corporis partium tabulae... T Gerlatzen: Nürnberg, 1572.

17 Varolio C. De nervis opticis... (1573), Facsimile edition Culture et Civilization: Brussels, 1969.

18 Descartes R. L'homme... (Treatise of man, 1664), Includes French translation and commentary by Thomas Steele Hall. Harvard University Press: Cambridge, 1972.

19 Van Leeuwenhock A. Epistolae physiologicae super compluribus naturae arcanis.... A Beman: Delphis, 1719.

20 Van Leeuwenhoek A. The collected letters of Antonie van Leeuwenhoek, Volumes 14 Swets \& Zeitlinger: Amsterdam, 1939.

21 Newton I. Opticks ..., 2nd ed. W \& J Innys: London, 1718.

22 Robinson B. A Dissertation on the Aether of Sir Isaac Newton. C Hitch: London, 1747.

23 Platter F. De corporis humani structura et usu libri III .... A Frobenium: Basel, 1583.

24 Kepler J. Ad Vitellionem paralipomena, Translated into French by Catherine Chevalley as Les fondaments de l'optique moderne: paralipomènes a Vitellion (1604). Libraire Philosophique J Vrin: Paris, 1980.

25 Scheiner C. Oculus. Hoc est ..., 2nd ed. Cornelium Bee: London, 1652.

26 Brøns J. The blind spot of Mariotte: Its Ordinary Imperceptibility or Filling-in and its Facultative Visibility. Nyt Nordisk Forlag, HK Lewis: Copenhagen \& London, 1939.

27 Todd RB, Bowman W. The Physiological Anatomy and Physiology of Man. JW Parker: London, 1856.

28 Cheselden W. The Anatomy of the Human Body, 7th ed. C Hitch \& R Dodsley: London, 1750.

29 Knapp H. The channel by which, in case of neuro-retinitis, the exudation proceeds from the brain into the eye. Trans Am Ophthalmol Soc 1870; 119.

30 von Graefe A. Ueber die Untersuchungen des Gesichtsfeldes bei amblyopischen. Arch Ophthalmol 1856; 2: 358-398.

31 von Haller A. Elementa physiologiae corporis humani. MM Bousquet, S d'Arnay, F Grasset, \& C Haak: Lausanne, Leyden, 1766.
32 Unzer JA, Prochaska G The principles of physiology (1771). A Dissertation on the Functions of the Nervous System (1784), Translated and edited in one volume by Thomas Laycock. Sydenham Society: London, 1851.

33 Hall M. Memoirs on some principles of pathology in the nervous system. Memoir III: on the distinct influence of volition, of emotion, and of the vis nervosa. MedicoChirurgical Trans (London) 1840; 22: 168-191.

34 Hunter J. Anatomical observations on the Torpedo. Philos Trans R Soc Lond 1774; 63(2): 481-489.

35 Cavendish $\mathrm{H}$. An account of some attempts to imitate the effects of the Torpedo by electricity. Philos Trans $R$ Soc Lond 1776; 1: 196-225.

36 von Humboldt A. Aspects of Nature in Different Lands and Different Climates. Translated by Mrs Sabine. Longman \& J Murray: London, 1849

37 Davy H. An account of some experiments on the Torpedo. Philos Trans R Soc Lond 1829; 1: 15-18.

38 Zinn JG. Descriptio anatomica oculi humani iconibus illustrata. A Vandenhoeck: Göttingen 1755.

39 Müller J. Elements of Physiology, Translated with notes by William Baly from Handbuch der Physiologie des Menschen für Vorlesungen (1835-1837). Taylor \& Walton: London, 1842.

40 du Bois-Reymond E. Vorläufiger Abriss einer Untersuchung über den sogenannten Froschstrom und über die elektromotischen Fische. Ann Phys Chem (Leipzig) 1843; 58: $1-30$.

41 Helmholtz H. Vorläufiger Bericht über die Fortpflanzungsgeschwindigkeit der Nervenreizung. Arch Anat Physiol Wissenschaftliche Med 1850; 71-73.

42 Clarke E, O'Malley CD. The Human Brain and Spinal Cord: A Historical Study Illustrated by Writings from Antiquity to the Twentieth Century, 2nd ed. Norman Publications: San Francisco, 1996.

43 Hoff HE, Geddes LA. Ballistics and the instrumentation of physiology: the velocity of the projectile and of the nerve impulse. J Hist Med Allied Sci 1960; 15: 133-146.

44 Hermann L. Lehr buch der physiologie, 13th ed. Berlin, 1905.

45 Adrian ED. The Mechanism of Nervous Action: Electrical Studies of the Neurone. University of Pennsylvania Press: Philadelphia, 1932.

46 Adrian ED. The Physical Background of Perception. Clarendon Press: Oxford, 1947.

47 Purkinje JE. Opera selecta Joannis Evangelistae Purkyne. Cura societatis Spolek ceskỳch lékaru: Prague, 1948.

48 von Kölliker A. Manual of Human Histology, Translated and edited by George Busk and Thomas Huxley. Sydenham Society: London, 1854.

49 Ranvier L. Leçons sur l'histologie du système nerveux. F Savy: Paris, 1878

50 Golgi C. Sulla fina anatomia degli organi centrali del sistema nervosa. Giunti: Florence, 1995.

51 Golgi C. Opera Omnia, 3 volumes Ulrico Hoepli: Milan, 1903.

52 y Cajal SR. Histology of the Nervous System of Man and Vertebrates, 2 volumes. English translation by Neely Swanson and Larry W Swanson. Oxford University Press: New York, Oxford, 1995.

53 Stricker S. Manual of Human and Comparative Histology, 3 volumes. Translated by Henry Power. New Sydenham Society: London, 1870.

54 Pagenstecher EH, Genth KP. Atlas der pathologischen Anatomie des Augapfels (Atlas of the Pathological Anatomy of the Eyeball). CW Kreidel: Wiesbaden, 1875. 
55 Loring EG. Text-book of Ophthalmoscopy. Hirschfeld Brothers: London, 1891.

56 Rosen G. The Specialization of Medicine with Particular Reference to Ophthalmology. Froben Press: New York, 1944.

57 Eldredge LM. A thirteenth-century ophthalmologist, Benevenutus Grassus: his treatise and its survival. $J R$ Soc Med 1998; 91: 47-52.

58 Grassus B. De oculis eorumque egritudinibus et cures (1474), Translated with notes by Casey A Wood. Stanford University Press: California, 1929.

59 Eldredge LM, Benevenutus Grassus. The Wonderful Art of the Eye, A critical edition of the Middle English translation of his De probatissima arte oculorum. Michigan State University Press: East Lansing, 1996.

60 Bayley W. A Brief Treatise Touching the Preservation of the Eie Sight ..., London, 1586. Facsimile reprint in Ophthalmodouleia: das ist, Augendienst ... George Bartisch. Tal Or Oth: New York, 1981.

61 Porter R. Quacks: Fakers and Charlatans in English Medicine. Tempus: Stroud, 2001.

62 Read SW. A Short but Exact Account of all the Diseases Incident to the Eyes ... (1710), Facsimile of second edition. Classics of Ophthalmology Library: Birmingham, Al, 1990.

63 Morgagni GB. The Seats and Causes of Diseases Investigated by Anatomy ... (1762), Abridged and annotated by William Cooke. Longman, Hurst et al: London, 1822.

64 Morgagni GB. The Clinical Consultations of Giambattista Morgagni, Translated and revised by Saul Jarcho. Francis A Countway Library of Medicine: Boston, 1984.

65 Lawrence W. A Treatise on the Diseases of the Eye (1833), Facsimile edition. Classics of Ophthalmology Library: Birmingham, Al, 1987.

66 Frick G. A Treatise on the Diseases of the Eye ... (1823), Facsimile edition. Classics of Ophthalmology Library: Birmingham, Al, 1985.

67 Scarpa A. Practical Observations on the Diseases of the Eye (1806), Translated from the Italian with notes by
James Briggs. Classics of Ophthalmology Library: Birmingham, Al, 1980.

68 Degravers P. A Complete Physico-medical and Chirurgical Treatise on the Human Eye, 2nd ed. Printed for the author: Edinburgh, 1788.

69 Beer G. The Art of Preserving the Sight Unimpaired to an Extreme Old Age ..., 2nd ed. Henry Colburn: London, 1815.

70 Mackenzie W. A Practical Treatise on the Diseases of the Eye. Longman, Rees et al: London, 1830.

71 Albert DM. The ophthalmoscope and retinovitreous surgery. In: Albert DM, Edwards DD, (eds) The History of Ophthalmology. Blackwell Science: Cambridge, MA, 1996.

72 Allbutt TC. On the Use of the Ophthalmoscope in Diseases of the Nervous System and of the Kidneys .... Macmillan \& Co: London, New York, 1871.

73 Hogg J. The Ophthalmoscope: Its Mode of Application Explained, and its Value Shown, in the Exploration of Internal Diseases Affecting the Eye. John Churchill: London, 1858.

74 Jaeger E. Ueber Staar und Staaroperationen. LW Seidel: Vienna, 1854.

75 Blanchard DL. Jaeger, about glaucoma. Hist Ophthalmol 1995; 89: 185-191.

76 Porter R, Rousseau GS. Gout: the Patrician Malady. Yale University Press: New Haven, London, 1998.

77 von Graefe A. Vorläufige Notize über das Wesen des Glaucoms. Arch Ophthalmol 1854; 1: 371-382.

78 Gowers SWR, Gunn M. A Manual and Atlas of Ophthalmoscopy, 4th ed. J \& A Churchill: London, 1904.

79 Lee R. On the Induction of Premature Labour in Cases of Pregnancy Complicated with Albuminous Urine, Dropsy and Amaurosis. JE Adlard: London, 1863.

80 Loring EG. Premature delivery for the prevention of blindness. Trans Am Ophthalmic Soc 1882; 423.

81 Cushing H. The Pituitary Body and its Disorders. JB Lippincott: Philadelphia, London, 1912.

82 Kuhn TS. The Structure of Scientific Revolutions. University of Chicago Press: Chicago, 1970. 